\title{
PENGEMBANGAN PROFESI GURU DALAM \\ MENINGKATKAN KINERJA GURU
}

\author{
Dinda Sri Utami \\ Email: dindasriutami07@gmail.com
}

\begin{abstract}
ABSTRAK
Berdasarkan jurnal supervisi pendidikan untuk meningkatkan profesionalitas guru berkelanjutan, dikatakan bahwa hasil belajar dan prestasi siwa di indonesia belum memuaskan dibandingkan dengan negara-negara lainnya. Hal ini disebebkan oleh kurang optimalnya kinerja guru dalam proses pembelajaran. Penelitian berfokus untuk membahas tentang proses pengembangan profesi guru untuk meningkatkan kinerjanya dan menghasilkan proses pembelajaran yang baik guna untuk meningkatkan prestasi dan hasil belajar siswa kedepannya. Pengambangan profesi ini dilakukan secaraberelanjutan da dilakukan dalam jangka waktu yang pantang secara terus menerus.
\end{abstract}

Kata Kunci: pengembangan profesionalisme guru, kinerja guru

\section{Latar Belakang}

Supervisi adalah pengawasan yang dilakukan secara profesional dalam bidang akademik yang dijalankan berdasarkan pada kaidah-kaidah keilmuan tentang bidang kerjanya, memahami tentang pembelajaran yang lebih mendalam, serta digunakan sebagai usaha untuk memberi layanan baik secara individual atau perseorang maupun memberikan layanan secara berkelompok kepada guru-guru guna untuk memperbaiki atau meningkatkan kinerja guru agar menjadi guru yang profesional.

Supervisi disini sangat berperan penting dalam pengembangan profesionalisme guru. Dimana supervisi digunakan untuk meningkatkan proses 
dan hasil belajar yang memerlukan motivasi yang kuat dari seorang guru, maka dari itu seorang supervisor perlu melakukan berbagai upaya untuk mengambangkan profesionalisme guru yang di supervisinya tersebut.

Pengembangan profesional guru merupakan proses yang berkelanjutan. Terdapat beberapa prinsip dalam pengembangan profesinal guru, diantaranya:

a. Memerlukan waktu yang lama untuk pelayanan yang menimbulkan efek permanen terhadap pembelajar yang dilakukan.

b. Peran sentral dalam pelatihan kerja disekolah.

c. Interaksi yang baik antar individu dengan lingkungan sangat mendukung dalam pengembangan profesionalisme guru.

Berdasarkan uraian di atas, permasalahan yang dibahas dalam tulisan ini adalah (1) Bagaimana peran supervisi dalam pengembangan profesionalisme guru? (2) Bagaimana peran supervisi dalam meningkatkan kinerja guru?

Tujuan penulisan ini adalah (1) untuk mengetahui peran supervisi dalam pengembangan profesionalisme guru dan (2) untuk mengetahui peran supervisi dalam meningkatkan kinerja guru.

\section{A. Kajian Literatur}

\section{Pengertian pengembangan profesionalisme guru}

Istilah pengembangan sumber daya manusia dalam keguruan sering dikenal dengan istilah teacher professional development yang merujuk pada aktivitas yang dilakukan untuk meningkatkan pertumbuhan karier profesional. Pengembangan profesional guru diartikan sebagai suatu kegiatan yang dilakukan untuk mengetahui apakah kemampuan guru dangan tuntutan pendidikan saat ini sesuai dengan keahlian dan keterampilan yang dimiliki oleh guru tersebut.

Pengembangan profesional ini diberikan dengan tujuan jangka panjang agar guru tersebut dapat memahami dan mengerti tentang pengajaran yang dilakukannya dan mengarti juga dengan keahlian yang dimilikinya agar dapat mengambangkan potensi yang dimiliki oleh guru tersebut. 
Berdasarkan pengertian diatas, pengembangan profesional ini merupakan suatu kegiatan yang berkelanjutan dalam jangka waktu yang lama. Ada beberapa prinsip dalam pengembangan profesional, yaitu:

a. Memerlukan waktu yang lama untuk pelayanan yang menimbulkan efek permanen terhadap pembelajar yang dilakukan.

b. Peran sentral dalam pelatihan kerja disekolah.

c. Interaksi yang baik antar individu dengan lingkungan sangat mendukung dalam pengembangan profesionalisme guru.

\section{Profesional guru melalui supervisi pendidikan}

Dalam hal ini, supervisi ditekankan dalam hal kerja sama dan memperbaiki profesional guru karena supervisi merupakan suatu alat yang sangat efektif untuk mengambangkan profesional guru.

Supervisi yang digunakan untuk mengambanagkan profesional guru berlandaskan pada beberapa prinsip yang telah diungkapakan dalam beberapa sumber atau literatur yang telah ada sebelumnya. Menurut Littel (1993) dalam nur aedi menyatakan bahwa tujuan utama supervisi adalah untuk para guru dan mengupayakan kerjasama anatar guru-guru tersebut dalam hal membangun kinerja yang aktif untuk meningkatkan pemahanan tentang proses belajar mengajar.

Menurut sabandi perkembangan supervisi pendidikan berkembang seiring dengan perkembangan ilmu pengetahuan, teknologi, serta sosial ekonomi dan budaya masyarakat. Supervisi bergerak dari berbentuk inspeksi dimana otoritas lebih didominasi oleh supervisor, berkembang dalam bentuk kolaborasi antara supervisor dan guru bersama berinisiatif dan bertanggungjawab dalam meningkatkan kualitas pembelajaran.(Sabandi, 2013)

supervisi dengan pengembangan profesional memiliki hubungan yang sangat erat. Dimana dalam pengembangan tradisional, pelaksanaan kegiatan dan pelayanan formal maupun informal telak dilaksanakan oleh guru pelatih secara langsung. Dalam hal ini supervisor hanya berperan sebagai fasilitator. 


\section{Peran supervisi dalam meningkatkan kinerja guru}

Supervisi berperan penting dalam meningkatkan kinerja guru, diantaranya sebagai berikut:

a. Untuk menunjukkan kelemahan serta upaya untuk memperbaiki dan pencegahan dari kelemahan tersebut.

b. Mengambil tindakan untuk memastikan agar tercapainya sesuatu tujuan yang diinginkan.

c. Untuk melihat kinerja guru dalam melaksanakan pembelajaran terhadap siswa

d. Untuk membangun hubungan yang harmonis dan baik antara sesama pegawai dan sesama guru disuatu sekolah.

e. Untuk memotivasi guru atau pegawai dalam melaksanakan tugasnya dengan baik.

f. Untuk mengukur dan menilai kemampuan yang dimiliki guru serta menilai seberapa besar ketercapaian kinerja dari guru tersebut.

\section{B. Pembahasan Analitis}

\section{Pengembangan Profesi Guru}

Pengambangan profesional guru diartikan sebagai suatu kegiatan yang dilakukan untuk mengetahui apakah kemampuan guru dangan tuntutan pendidikan saat ini sesuai dengan keahlian dan keterampilan yang dimiliki oleh guru tersebut. Pengembangan ini diarahkan untuk melakukan prningkatan pada kinerja guru dilingkungan sekolah, penilai dari kinerja guru yang dilakukan secara objektif, transparan dan akuntabilitas, serta mendorong untuk meningkatkan prestasi dari guru tersebut.

Menurut putri ayu dwi kesuma, pengembanganprofesi guruadalah kegiatanguru dalampengamalanilmu dan pengetahuan, teknologidan keterampilan untukmeningkatkan mutu, baik bagi proses belajarmengajardan profesionalisme tenaga kependidikan lainnya.(Putri, 2017) 
Pengembangan profesi seorang pendidik merupakan suatu yang sangat penting, dimana pengembangan merupakan pertumbuhan secara umum yang tidak terfokus pada pekerjaan tertentu. Pengembangan profesi guru mengklasifikasikan beberapa indikator dalam pengembangan profesi tersebut, diantaranya:

1. Mengikuti informasi sesuai perkembangan IPTEK yang menjadi pendukung dari profesi tersebut

2. Menggunakan berbagai metode pembelajaran yang bervariasi

3. Menggunakan media sebagai alat peraga

4. Mengikuti perkembangan kurikulum yang selalu berkelanjutan

Pengembangan profesi guru merupakan suatu proses kegiatan yang berjalan terus menerus. Guru atau pendidik merupakan sesuatu paling penting dalam proses pendidikan, sehingga kualitas pendidikan banyak ditentukan oleh kualitas seorang pendidik ketika menjalankan tugasnya.

\section{Kinerja Guru}

Kinerja guru adalah suatu hasil atau kemampuan guru dalam menunjukkan keahlian atau potensi yang dimilikinya. Kinerja guru juga merupakan suatu bentuk dari hasil usaha seorang pendidik untuk mencapai tujuan pendidikan.

Kinerja guru adalah suatu proses pembelajaran sebagai upaya dalam mengembangkan suatu kegiatan yang telah ada untuk menjadi kegiatan yang lebih baik, sehingga tujuan pendidikan yang telah ditentukan dapat tercapai melalui kegiatan pembelajaran yang dilakukan dengan tujuan atau terget yang telah ditentukan.

Upaya yang dapat dilakukan dalam meningkatkan kinerja guru yaitu: melaksanakan pembinaan akademik kepada guru-guru, memberikan tambahan tugas pada guru baru dan memberikan penghargaan atau reward kepada guru yang berpartisipasi dan memberikan hukuman kepada guru yang malas serta tidak melaksanakan tugas dengan baik. 


\section{Kesimpulan Dan Saran}

\section{Kesimpulan}

Supervisi adalah pengawasan yang dilakukan secara profesional dalam bidang akademik yang dilakukan berdasarkan pedoman keilmuan tentang dibidang kerja tertentu, dan mengetahui tentang proses pembelajaran untuk lebih mendalaminya, serta digunakan untuk melakukan layanan secara baik kepada individu baik secara kelompok maupun secara perorangan kepada guru untuk meningkatkan profesionalisme dan kinerja dari guru tersebut.

Pengembangan profesionalisme guru diartikan sebagai suatu kegiatan yang dilakukan untuk mengetahui apakah kemampuan guru dangan tuntutan pendidikan saat ini sesuai dengan keahlian dan keterampilan yang dimiliki oleh guru tersebut.Peningkatan kinerja guru dilakukan untuk meningkatkan dan mengambangkan potensi yang ada pada guru tersebut yang dilakukann dalam jangka waktu yang lama dan dilakukan secara terus menerus atau berelanjutan.

\section{Saran}

Diharapkan kepada pembaca setelah memahami isi dari laporan analisis jurnalini agar dapat memahami tentang pengembangan profesional guru dalam meningkatkan kinerja guru. 


\section{REFERENSI}

Putri, ayu dwi kesuma. (2017). Pengembangan profesi guru dalam meningkatkan kinerja guru. PENDIDIKAN MANAJEMEN PERKANTORAN, 1(1), 1-9. Retrieved from ejournal.upi.edu/index.php/jpmanper/article/download/...

Sabandi, A. (2013). SUPERVISI PENDIDIKAN UNTUK PENGEMBANGAN PROFESIONALITAS GURU BERKELANJUTAN. Pedagogi, Jurnal Ilmiah Ilmu Pendidikan, XIII(2), 1-9. Retrieved from http://ejournal.unp.ac.id/index.php/pedagogi/article/view/4275 